\title{
STRATEGI PENGEMBANGAN KOMUNIKASI MASYARAKAT KELOMPOK TANI QORYAH TOYYIBAH DI KALIBENING KECAMATAN TINGKIR KOTA SALATIGA
}

\author{
Ilyas \\ Dosen Pendidikan Luar Sekolah UNNES Semarang \\ Sabatalfian12@gmail.com
}

\begin{abstract}
This research was aimed to reveal strategy of society communication development within Qoryah Thoyyibah farmer association, through the farmer effort to increase organic rice plant commodity. This research used descriptive qualitative approach and method where the data were collected through observation, interview, documentation, and it also used triangulation of resource, data, and theory. The research subjects were the member and the committee of Qoryah Toyyibah farmer association at Kalibening, Tingkir district of Salatiga city. Through society empowerment, farmer association of organic rice plant commodity economically has raised their welfare better through cooperatives system where it becomes the alternative activity in management especially about financial that involves farmer crop starting from planting process, maintenance process, up to crop yield management. Moreover, the strategy of society communication of farmer association was able to strengthen the friendship among the member by implementing Javanese culture philosophy, mutual assistance, friendly and peaceful communication in monthly meeting conducted.
\end{abstract}

Keywords: Development, Organic Rice, Qoryah Toyyibah Society

\begin{abstract}
Abstrak
Penelitian bertujuan mengungkap strategi pengembangan komunikasi masyarakat Kelompok Tani Qoryah Toyyibah melalui usaha para petani untuk meningkatkan komoditas tanaman padi organik. Metode yang digunakan kualitatif diskritif, melalui observasi, wawancara, dokumentasi, dengan menggunakan trianggulasi sumber, data, dan teori. Subjek telitinya adalah anggota dan pengurus kelompok tani Qoryah Toyyibah di Kalibening Kecamatan Tingkir Kota Salatiga. Melalui pemberdayaan masyarakat kelompok tani komoditas tanaman padi organik ini secara ekonomis meningkatkan kesejahteraan dengan hasil yang baik melalui sistem perkoperasian sebagai wadah aktifitas dalam manajemen terutama masalah keuangan. Berangkat dari proses menjelang penanaman, proses perawatan, sampai manajemen hasil panen, selain, strategi komunikasi masyarakat mampu mempererat tali silaturahim antaranggota, dengan selalu menjunjung tinggi nilai falsafah budaya Jawa, gotong royong, guyub, rukun dalam bentuk dan cara diadakannya pertemuan rutin bulanan.
\end{abstract}

Kata Kunci: Pengembangan, Padi Organik, Masyarakat Qoryah Toyyibah

\section{Pendahuluan}

Salah satu fungsi pemerintahan adalah tanggung jawab terhadap kebutuhan primer rakyatnya, terlebih dalam kebutuhan pangan. Apabila pemerintah mampu memecahkan problematika rakyat paling dasar ini berarti indikasi dasarnya adalah pemerintah dapat dipercaya untuk mengelola negara untuk dapat menjalankan roda pemerintahannya. Persoalan pangan tidak bisa dianggap masalah sederhana, terlebih ketika realitas 
Indonesia dengan jumlah penduduk yang hampir tigaratus juta jiwa. Jika dalam hal ini pemerintah tidak serius menangani perihal ketahanan pangan ini, maka akan menjadi bom waktu persoalan tersebut muncul ke permukaan.

Pada kasus Indonesia dewasa ini, ketahanan pangan bagi pemerintah belum maksimal dalam menangani persoalan pangan, sehingga masih banyak tanah-tanah yang kurang produktif dibiarkan begitu saja. Sementara, disisi lain banyak alih fungsi tanah yang produktif dijadikan lahan pemukiman, pabrik, dan gedung-gedung bisnis lain di luar konsep pangan, dan ditambah perilaku rakyat yang tergiur dengan iming-iming uang, namun mereka harus kehilangan aset besar yang berupa tanah pertanian. Apabila hal ini pemerintah tidak segera turun tangan secara serius maka bencana kekurangan pangan pasti terjadi dan mengancam persoalan ketahanan pangan.

Bicara ketahanan pangan di Indonesia tentu tidak bisa lepas dari padi sebagai makanan pokok, karena padi merupakan kebutuhan pangan utama. Jumlah padi dari tahun ke tahun mengalami penurunan yang sangat tajam dari segi hasil produktifitasnya, di berbagai lumbung padi di Indonesia pada umumnya dan Jawa Tengan khususnya, karena Jawa Tengah merupakan salah satu sentra produksi utama tanaman padi (Sucihatiningsih, 2010:14). Namun pada kenyatannya fungsi pemerintah dalam bidang pertanian, hal ini Kementerian Pertanian sebagai penanggungjawab tidak lebih dari sekedar perusahaan penjual obat pestisida pertanian dan sampai detik ini belum mampu menjawab persoalan besar bangsa ini.

Secara rasional sulit diterima, Indonesia sebagai negara agraris masih melakukan import beras dari negara-negara kecil, seperti Vietnam yang baru beberapa tahun merdeka. Apa yang salah terhadap pengelolaan negara ini? Benarkah kita kekurangan beras? Adakah faktor lain yang menyebabkan terjadinya import beras itu dan bukan karena kekurangan? Belum hilang ingatan tentang kisruh kuota import gula, import daging sapi, itu hanya sederet kecil perilaku yang memperlemah posisi Negara Indonesia yang terkenal dengan negara yang subur dan makmur. Mustahil rasanya jika harus mengimpor berbagai hasil pertanian dari negeri luar yang jauh lebih rendah tingkat kesuburan dan kemakmurannya. Sebagaimana pendapat dari Emha Ainun Nadjib dalam suatu Kajian Gambang Syafaat edisi tanggal 25, Oktober 2015 di Masjid Raya Baiturrahman Semarang. Beliau mengatakan bahwa kebanyakan kasus impor beberapa kebutuhan barang di Indonesia bukan karena kekurangan akan tetapi karena karakter pejabat pengelola terkait belum maksimal. 
Lebih jauh Emha Ainun Nadjib, mengidentifikasi persoalan-persoalan mengapa produktifitas padi dari tahun ke tahun banyak mengalami penurunan? Hal itu banyak berbagai alasan diantaranya adalah; Pertama, lahan pertanian produktif sudah sangat berkurang karena dari petani dijual ke kapitalis-kapitalis dengan berbagai iming-iming harga untuk keperluan industri, dan perumahan. Kedua, keberpihakan pemerintah kepada petani sangat minim sekali. Ketiga, pemerintah lebih memihak kepada perusahaan pestisida daripada ketahanan pangan rakyat dalam jangka panjang. Keempat, kepicikan pejabat terkait yang sangat kurang memiliki nurani kepada rakyat.

Sebagian keputusan pemerintah, baik dari pusat sampai kepada tingkat daerah tidak meyadari bahwa Tuhan memberikan potensi kepada bangsa Indonesia dalam bentuk agrasis dan kemaritiman, yang dengan dua potensi inilah mestinya pemerintah dengan serius mengelolanya, dan bukan menjadikan Indonesia menuju negara industri, yang bertentangan dengan potensi kearifan lokal yang ada.

Hal itu terkadang lupa untuk disadari bahwa betapa pentingnya produksi utama kebutuhan padi, sebagaimana kata Syahyuti et.al (2003:45) bahwa sektor pertanian menjadi salah satu strategi untuk recovery sekaligus memberikan landasan bagi perkembangan sektor riil pada krisis ekonomi yang dialami Indonesia sejak tahun 1997. Hal ini dapat dibuktikan dengan daya hidupnya yang tinggi ketika sektor lain runtuh.

Ciri khas usaha pada sektor pertanian adalah melibatkan banyak orang dengan kepemilikan sumber daya dan keterampilan yang rendah, serta social network yang kurang mendukung, khususnya untuk memasuki ekonomi modern saat ini. Pada konteks hari ini, walaupun produktivitas padi dilakukan secara maksimal, belumlah cukup untuk meningkatkan kesejahteraan kelompok tani. Para petani harus ditumbuhkan sejak dini, tanggap atas permintaan pasar, kualitas panen, dan bahkan harus lebih dari itu semua, apakah panen berdampak pada kesejahteraan masyarakat petani. Itu pertanyaan sekarang yang harus dijawab.

Secara kesehatan dan kesuburan tanah, yang selama ini petani sangat tergantung pada pestisida, sudah banyak menjadi perhatian. Hasil pertanian dengan pestisida secara kualitas padi kurang bagus baik pada segi kuantitas dan kualitas. Secara kuantitas hasil panen tahun ke tahun mengalami penurunan, karena tanah sudah tergantung dengan pestisida. Selain penurunan kuatitas, penurunan kualitas sangat terasa sekali bagi para petani, bahwa kualitas padi pestisida tidak bisa bertahan lama ketika sudah menjadi nasi, artinya proses pembusukannya lebih cepat, serta bagi kesehatan tubuh pengonsumsinya 
Inject, Interdisciplinary Journal of Communication, Vol. 1, No. 2, Desember 2016: 113-126

kurang baik, sehingga dari persoalan tersebut di atas petani dituntut untuk punya kreatifitas dan inovasi yang lebih tinggi.

Berikut ini beberapa kelebihan padi organik; Tanah tidak rusak, karena sangat sedikit kimia yang terkandung, baik dari pemupukan dan pengobatan; Hasil produksi dari tahun ke tahun semakin meningkat; Harga jual padi organik lebih tinggi bahkan bisa sampai limapuluh persen dibanding padi tidak organik; Peluang pasar sangat terbuka dan cukup besar; Sangat baik, dan sehat untuk dikonsumsi; Serta Ramah lingkungan (Mustofa, 2013:57). Dari beberapa fakta tersebut di atas, kiranya petani untuk segera berkemas-kemas untuk kembali ke masa lalu yang pernah jaya dan mejadi dambaan pekerjaan manyarakat. Karena bertani menjadi sehat, berkah, dan tidak ada unsur merusak sebagaimana frekuensi kepada Tuhan tersambung, tidak seperti sekarang, yang bertani dengan menggunakan kimia pada gilirannya merusak ekosistem, tidak sehat, untuk mencapai hal tersebut harus diperlukan kerja sama pemerintah, dan pihak-pihak terkait karena tanpa pemerintah berperan akan sangat sulit jadi kenyataan.

\section{Permasalahan}

Fokus masalah ini dapat diuraikan sebagai berikut; (a) Bagaimana gambaran masyarakat muslim kelompok tani qoryah tayyibah? (b) Bagaimana pengembangan masyarakat kelompok usaha tani? (c) Bagaimana rancangan dalam meningkatkan komoditas tanaman padi organik kelompok tani qoryah tayyibah?

\section{Komunikasi Masyarakat}

Menurut Stuart dalam (Vardiansyah, 2004:3). Bahwa kata, komunikasi, berasal dari bahasa latin, comunis, yang berarti membuat kebersamaan atau membangun kebersamaan antara dua orang atau lebih. Akar katanya, communis adalah communico yang artinya berbagi Sedangkan kata, masyarakat, berasal dari bahasa Arab, yaitu Syiek, artinya, bergaul. Adanya saling bergaul ini tentu karena ada bentuk-bentuk akhiran hidup, yang bukan disebabkan oleh manusia sebagai pribadi melainkan oleh unsurunsur kekuatan lain dalam lingkungan sosial yang merupakan kesatuan

Perumusan dan pengembangan konsep masyarakat menggunakan projecting back theory, yang berangkat dari sebuah hadits yang mengatakan, Khayr al-Qurun qarni thumma al-ladhi yalunahu thumma al-ladhi yalunahu, yaitu dalam menetapkan ukuran baik atau buruknya perilaku harus dengan merujuk pada kejadian yang terdapat dalam 
khazanah sejarah masa awal Islam (Hamim, 2000:115-127). Kemudian para cendekiawan muslim mengislamkan konsep civil society yang lahir di Barat dengan masyarakat madani, suatu masyarakat kota Madinah bentukan Nabi Muhammad SAW. Mereka mengambil contoh dari data historis Islam yang secara kualitatif dapat dibandingkan dengan masyarakat ideal dalam konsep civil society.

Mereka melakukan penyetaraan itu untuk menunjukkan di satu sisi, Islam mempunyai kemampuan untuk diinterpretasi ulang sesuai dengan perkembangan zaman, dan di sisi lain, masyarakat kota Madinah merupakan proto-type masyarakat idel produk Islam yang bisa dipersandingkan dengan masyarakat ideal dalam konsep civil society. Tentunya penggunaan konsep masyarakat madani dilakukan setelah teruji validitasnya berdasarkan landasan normatif (nass) dari sumber primer Islam (al-Qur'an dan Hadits) atau dengan praktek generasi awal Islam (the Islamic era par exellence).

\section{Pengembangan Masyarakat; Konsep dan Cakupan}

Pengembangan masyarakat sebagai salah satu hal penting terhadap upaya menolong anggota masyarakat yang memiliki kesamaan minat untuk bekerja sama, mengidentifikasi kebutuhan bersama dan kemudian melakukan kegiatan bersama untuk memenuhi kebutuhan tersebut. pengembangan masyarakat seringkali diimplementasikan dalam bentuk (a) proyek-proyek pembangunan yang memungkinkan anggota masyarakat memperoleh dukungan dalam memenuhi kebutuhannya atau melalui (b) kampanye dan aksi sosial yang memungkinkan kebutuhan-kebutuhan tersebut dapat dipenuhi oleh pihak-pihak lain yang bertanggungjawab (Payne, 1995:165).

Pengembangan masyarakat terdiri dari dua konsep, yaitu "pengembangan" dan "masyarakat". Secara singkat, pengembangan atau pembangunan merupakan usaha bersama dan terencana untuk meningkatkan kualitas kehidupan manusia. Bidangbidang pembangunan biasanya meliputi beberapa sektor, yaitu ekonomi, pendidikan, kesehatan dan sosial-budaya. Masyarakat dapat diartikan dalam dua konsep, yaitu (Mayo, 1998:162).

\section{Langkah-langkah Pengembangan Masyarakat}

Langkah dalam pengembangan masyarakat harus mengetahui lebih jauh terkait dengan prinsip-prinsip pengembangan masyarakat, namun dari sekian banyak prinsip 
yang ada, pokok intinya adalah partisipasi, kemandirian dan kewasdaan. Dalam partisipasi ditujukan pada setiap program melibatkan masyarakat, baik fisik, ide, dan materi. Keterlibatan pengembangan masyarakat memiliki makna keikutsertaan masyarakat secara fisikal dan mentalitas. Program selalu berasal dan untuk pemenuhan masyarakat, sehingga yang merencanakan adalah agen bersama masyarakat. Kemandirian artinya tujuan utama dari program untuk mengentaskan masyarakat dengan dirinya sendiri, dan peneliti hanya sekedar memberi stimulasi gagasan. Kewaspadaan bahwa setiap program harus dilakukan dengan kemampuan diri sendiri, sehingga segala bentuk intervensi hanyalah sebagai insentif saja (Tonny, 2014:117)

Adapun langkah-langkah pemberdayaan masyarakat dapat dilakukan dengan memperhatikan sebagai berikut; Pertama, melakukan analisis kebutuhan. Seseorang agen harus dapat mengenali apa sesungguhnya yang menjadi kebutuhan masyarakat. Ia harus melakukan need assesment. Analisis kebutuhan dimaksudkan agar tidak terjadi kekeliruan di dalam memetakan apa yang mestinya diperbuat untuk pemberdayaan masyarakat. Kedua, melakukan analisis situasi sosial atau social analysis, yaitu melakukan kajian terhadap berbagai hambatan dan potensi, baik fisik maupun non-fisik yang mempengaruhi atas hidupnya masyarakat, dan kemudian menempatkan hasil analisis kebutuhan tersebut di dalam peta hambatan dan potensi yang dimaksud. Ketiga, menemukan berbagai program yang layak dijadikan sebagai basis pengembangan masyarkat, mungkin akan ditemui sekian banyak program yang relevan dengan analisis kebutuhan dan analisis situasi sosialnya. Keempat, menentukan alternatif program yang diprioritaskan. Kelima, melakukan aksi pemberdayaan masyarakat sesuai dengan program prioritaskan. Keenam, melakukan evaluasi untuk mengetahui keberhasilan atau kegagalan program dan faktor-faktor penyebabnya. Melalui evaluasi ini akan ditindaklanjuti program berikutnya. (Tonny, 2014:117)

\section{Metode Penelitian}

Penelitian ini menggunakan pendekatan kualitatif diskriptif yaitu penelitian yang menghasilkan dan mengolah data yang sifatnya deskriptif, untuk menggambarkan, mengungkap, dan menjelaskan strategi pengembangan komunikasi masyarakat Kelompok Tani Qoryah Toyyibah di Kalibening Kecamatan Tingkir Kota Salatiga, melalui usaha para petani untuk meningkatkan komoditas tanaman padi organik. 
Penelitian ini dilakukan pada kelompok tani Qoryah Toyyibah di Kalibening Kecamatan Tingkir Kota Salatiga, selama enam bulan.

Penetapan subyek penelitian atau informan dipilih subyek pertama sebagai informan kunci yaitu informan yang didasarkan pertimbangan tertentu memenuhi syarat sebagai informan yang sangat mengetahui aspek-aspek permasalahan yang diteliti, Subyek penelitian sebagai informan dalam penelitian ini terdiri dari anggota kelompok tani Qoryah Toyyibah. Teknik pengumpulan data yang dipakai dalam penelitian ini adalah observasi partisipasi, wawancara mendalam (in-depth interviewing) dan teknik dokumentasi.

\section{Gambaran Masyarakat Muslim Kelompok Tani Qoryah Tayyibah}

Masyarakat Muslim Kelompok Tani Qoryah Tayyibah yang secara organisasi berada di Kelurahan Kalibening Kecamatan Kota Salatiga. Pada awalnya kelompok ini bergerak pada sektor pertanian khususnya pada tanaman padi organik namun pada perkembangannya kelompok Tani Qoryah Tayyibah ini berkembang pada pendidikan dan pendampingan. Kelompok Tani Qoryah Tayyibah ini secara organisasi memang ada di Kelurahan Kalibening Kota Salatiga. Namun secara keanggotaan kelompok terdiri dari masyarakat Salatiga dan sekitarnya, termasuk didalamnya masyarakat Kabupaten Semarang dan Kabupaten Boyolali.

Secara keanggotaan, pada mulanya kelompok ini hanya berjumlah puluhan namun pada proses perkembangannya mencapai ratusan anggota. Berdirinya Kelompok Tani Qoryah Tayyibah berangkat dari keprihatinan petani baik dari hasil tani yang kurang maksimal, penyebaran zat kimia di tanah pertanian yang semakin luas dan tidak terkendali, dan hasil pertanian terutama padi yang secara pertanian kurang sehat. Berangkat dari keprihatinan tersebut di atas yang saat ini diketuai oleh Mustofa yang ingin menjawab sekian banyak kegelisahan petani selalu tergantung dengan petisida.

Dalam perkembangannya kegiatan ini banyak mengalami kendala karena pada awalnya yang ditawarkan kelompok tani tersebut kuranglah populer dimata petani yang sudah punya ketergantungan terhadapap pestisida. Namun, lambat laun dengan usaha yang terus menerus tanpa mengenal lelah usaha tersebut mampu membuktikan kepada masyarakat bahwa usaha tani organik adalah model bertani masa depan yang sehat, produktif, tidak merusak lingkungan, sebagaimana peran manusia sebagai khalifah untuk 
Inject, Interdisciplinary Journal of Communication, Vol. 1, No. 2, Desember 2016: 113-126

menjadi manager alam agar semua keputusan-keputusan manusia memberi manfaat kapada seluruh alam, rahmatan lil alamin, tidak melakukan perusakan terhadap alam.

Sebelum usaha tani organik ini muncul, pada umumnya petani memakai cara-cara yang ditawarkan pemerintah dengan tergantung dengan pestisida, yang sudah diketahui bahwa hasil produksi bertani dengan pestisida semakin hari hasilnya semakin tidak ramah lingkungan, tanah menjadi tidak subur karena mengandung zat kimia, produktivitas semakin menurun, hasilnya pun kurang sehat.

\section{Pengembangan Masyarakat Kelompok Usaha Tani}

Peningkatan komoditas tanaman padi organik untuk kesejahteraan anggotanya, Kelompok Tani Qaryah Tayyibah secara karakter memiliki mekanisme budidaya dan pemasaran yang berbeda dengan usaha tani lainnya. Budidaya pada kelompok ini lebih mengedepankan pada ramah lingkungan dalam proses pengolahan tanah. Kelompok ini mempunyai karakteristik, salah satu persyaratan usaha harus memiliki karakteristik yang berbeda dengan orang atau kelompok lain (Suryana, 2007:10).

Tahap awal pengolahan tanah dilakukan dengan cara mencangkul atau membajak sebagaimana pada umumnya kemudian tanah tersebut dibiarkan beberapa saat antara satu sampai dua minggu, agar tanah tersebut memiliki penggemburan sehingga tanah bisa melakukan proses secara alamiah pada akhirnya tanah tersebut mampu memproduksi pupuk secara alamiah hal itu dibuktikan dengan tanah yang semakin gembur dan didalam tanah terdapat cacing-cacing kecil. Sesudah panen sebanyak dua kali biasanya masuk pada musim kemarau, sehingga tanah mengalami proses alamiah.

Setelah masuk musim tanam dengan perhitungan teknis tanah diratakan dengan dibajak, dibiarkan selama satu mingguan, dan kemudian tanah digaru atau diratakan kembali. Setelah melewati dua atau tiga hari tanah siap ditanami. Langkah penanamannya sebagai berikut; Dalam satu petak tanah tahap awal sudah ditanami bibit, namun penanaman bibit tersebut hanya ada di sekeliling petakan, kemudian di tengah dibagi dengan ukuran tertentu, hal ini dilakukan untuk menjadi patokan penanaman berikutnya; Benih padi diletakkan di tengah-tengah, samping kanan kiri sudut sawah, dengan cara diikat masing-masing ikatan berisi sekitar searatus biji dan diletakkan dengan kepadatan yang telah diperhitungkan ukuran dan populasinya; Langkah pertama tidak langsung ditanam tanpa memerhatikan ukuran begitu saja, penanaman benih padi dengan menggunakan ukuran blak, yaitu suatu penggaris dibuat dari bambu yang ukuran panjangnya tiga meter kemudian pada bambu tersebut ditandai 
atau jarak yang berukuran satu dengan lainnya sekitar sepuluh sampai limabelas sentimeter, sebagai acuan menanam agar teratur, rapi, serta agar perkembangan padi yang ditanam mempunyai hak untuk berkembang secara sama, mempunyai ruang untuk beranak dengan populasi yang sama, yang pada akhirnya hasil perkembangannya bisa maksimal.

Proses perawatan dilakukan dengan dua tahapan. Tahap pertama adalah dengan matun atau membersihkan rumput dan kotoran yang menggangu pertumbuhan padi. Proses matun ini dilakukan dengan cara mendorong di tengah-tengah tanaman padi yang masih kecil dengan menggunakan balok kayu ukuran sepuluh sentimeter kali duapuluh sentimeter yang diberi kayu sebagai pegangan, kemudian di bawahnya dipasang paku yang panjannya sekitar sepuluh sentimeter sebagai fungsi menghancurkan tanah yang ada rumput-rumput pengganggu tanaman padi. Untuk rumput besar tidak dilakukan dengan cara demikian, namun dengan cara mencabuti dengan menggunakan tangan.

Tahap pemupukan dan proses perawatan padi dalam pemupukan dilakukan dengan dua langkah diataranya adalah; Pertama, dengan cara sebelum padi ditanam sudah ditebarkan pupuk organik (pupuk kandang) yang merata keseluruh tanah yang akan ditanami. Pemupukan pada proses perkembangannya untuk asupan pupuk lainnya bisa dilakukan dengan cara pemberian urin dari sapi bagi mereka yang mempunyai; Kedua, setelah padi tumbuh pada usia tiga minggunan dilakukan pemupukan dengan pupuk organik yang telah disiapkan, untuk merangsang pertumbuhan padi dalam masa pertumbuhan.

Setelah srategi penanaman dilakukan kelompok ini yang pertama kali dilakukan adalah mengidentifikasi lingkungan lahan pertanian di Salatiga dan sekitarnya, dari luas tanah sampai pada hasil produksi padi dalam satu tahun, setelah mendapatkan data mendekati valid langkah berikutnya melakukan ke petani di Salatiga dan sekitarnya yang telah direncanakan untuk mensosialisasikan visi dan misinya dilakukan melalui kelompok-kelompok diantaranya adalah; Kelompok jamaah pengajian mingguan dan bulanan; Karena sasaran utamanya adalah petani yang beragama Islam; Pesantren salafi dan lembaga-lembaga disekitarnya. Mereka memiliki kesadaran yang baik karena sebagian petani di wilayah Salatiga dan sekitarnya adalah beragama Islam didukung dengan banyaknya pondok pesantren yang ada di sekitar Kota Salatiga, maka melalui cara itu hasilnya cukup signifikan dalam mencapai visi dan misinya. Setelah mengidentifikasi anggota, tahapan berikutnya adalah mengukur kekuatan produksi 
anggotanya dalam setiap tahun. Pada saat ini hasil produksi padi organik Kelompok Tani Qoriyah Toyyibah masih belum maksimal apabila diukur dari target yang dicanangkan sekitar seribu ton, diperkirakan capaian baru berkisar delapan ratus lima puluh ton atau sekitar tujuh puluh lima persen pada tahun 2016.

Kelemahan pada produksi yang anorganik adalah ketika musim kurang menentu akibat dari lingkungan eksternal, artinya karena tidak semua petani di daerah Salatiga dan sekitarnya mau menggunakan metode organik maka dengan sendirinya akan timbul masalah secara eksternal, misalnya waktu menanam benih padi pertama tidak dilakukan secara bersama sama hal itu disaat penanaman tidak dilakukan secara bersama dengan lingkungannya bisa timbul hama yang tidak terduga misalnya, hama tikus yang selama ini sering ada, faktor eksternal lainnya pada masalah pengairan. Bagi mereka (petani organik) mempunyai lahan di tengah-tengah atau yang diapit dengan petani pestisida hal ini akan sangat mengganggu kebutuhan irigasi pertanian organik karena untuk mendapatkan air dari irigasi bagi petani yang lahannya di tengah harus melewati lahan pertanian pestisida disitulah zat kimia dari pestisida akan terbawa masuk kelahan pertanian organik memlalui sistem pengairan dan pada akhirnya akan berdampak pada kesuburan tanah dan tentu pada ketahanan padi sampai pada hasilnya kurang maksimal.

\section{Keberhasilan Strategi Pemberdayaan yang Dirancang}

Tahap awal pengurus menargetkan jumlah anggota sebanyak-banyaknya, hal ini dengan asumsi semakin banyak anggota semakin baik, idealnya semua komplek lokasi bisa ditanami organik, karena apabila satu komplek bisa ditanami organik semua pengendalian yang menyangkut masalah teknis sangat mudah, mengapa demikian? Karena cara koordinasi baik dari pengolahan, perawatan, sampai panen dibutuhkan koordinasi intensif, apabila lokasi berjauhan akan sangat menyulitkan koordinasi. demikian kata Mustofa dalam wawancara.

Lebih lanjut beliau mengatakan bahwa ada banyak keuntungan apabila satu komplek lokasi bisa ikut semua selain koordinasinya mudah, aspek teknis dalam perawatan lebih mudah, karena bisa ada kebersamaan dalam proses penanaman, pengairan, pemupukan sampai pada pemanenan, sudah barang tentu cara mengatasi hama disaat diserang relatif lebih mudah.

Dari rancangan untuk mencari anggota sebanyak-banyaknya ternyata belum bisa maksimal, pada proses berjalannya waktu disaat sosialisasi pertama yang dilakukan di pondok pesantren dan kelompok-kelompok pengajian hanya sepuluh persen mereka yang 
mau menerima tawaran untuk bergabung dengan kelompok tani, Sembilan puluh persen lainnya masih bertahan dengan metode lama dengan menggunakan pestisida, karena pada umumnya mereka takut dengan resiko yang begitu besar menghantui pemikiran mereka, baru pada perjalanan berkisar tiga tahun secara berlahan anggota kelompok ini mulai bertambah banyak, anggota yang menyusul pada umumnya mau mengerti dulu hasilnya, sebelum dia mengerti hasilnya pada umumnya mereka masih belum bisa percaya, meskipun yang mengajak teman dekatnya sendiri. Hal senada juga diungkapkan oleh Asrori, beliau menegaskan bahwa memang petani lain yang ikut gabung setelah berjalan tiga tahun mereka ingin melihat bukti dari program organik tersebut. Setelah berjalannya waktu sampai saat ini jumlah anggota mencapai delapanpuluh lima persen dari target yang dirancang, namun hal itu tidaklah mudah untuk mempengaruhi agar program ini diterima di kalangan petani. Rancangan program sangat penting karena tanpa rancangan dan target, sesuatu tidak bisa dikonrol tingkat keberhasilannya, didalam perencanaan tersebut harus terlihat jelas faktor-faktor yang mempengaruhi (Suryana, 2007:42).

Dengan asumsi jumlah anggota semakin mencapai titik optimal berarti aspek target produksi semakin mendekati titik ideal, karena jumlah anggota akan berbanding lurus dengan produktivitas hasil padi organik. Strategi penambahan anggota ini pada perjalanan menjadi tangung jawab semua anggota dengan cara masing-masing anggota ada kewajiban dari pengurus untuk mencari tambahan anggota, nampaknya hal ini lebih efektif, selain dengan cara tersebut, untuk mempertahankan anggota mereka melakukan pertemuan-pertemuan rutin dalam satu bulan sekali, namun dalam pertemuan tersebut selalu dibungkus dengan kegiatan, karena mereka pada sadar bahwa anggota kelompok tani semuanya beragama Islam, maka pada setiap kegiatan mereka baik koordinasi atau apapun selalu tidak bisa lepas dari kegiatan Islam.

Dalam usaha peningkatan komoditas tanaman padi pengurus melakukan beberapa terobosan diantaranya dengan cara; Pertama, mendatangkan beberapa tenaga ahli dari luar yang menyangkut tentang problematika dalam menghadapi serangan hama; Kedua, belajar manajemen produksi terutama ketika terjadi panen raya semua anggota diwajibkan untuk menjual produksinya kepengurus, hal itu dilakukan untuk melindungi harga pasar stabil; Ketiga, pengurus melakukan pelatihan kepada anggota untuk mengenali kualitas hasil produksi padi organik; Setelah padi organik diproses menjadi beras dibutuhkan teknik packing yang baik karena packing itu akan menentukan harga 
pasar. Kelompok ada kegiatan memperluas tanaman padi yang semula hanya bertumpu pada padi jenis C4 yang sekarang sudah merambah ke jenis padi lainnya diantarnya adalah jenis padi mentik wangi, pandan wangi, dan beras merah.

Apabila petani sadar mau membuka diri dengan pihak luar maka pekerjaan bertani justru menjadi dambaan setiap orang, karena dengan mau membuka diri, dan belajar potensi petani akan bisa maksimal, kelemahan petani Indonesia selalu bergantung pada pemerintah, sehingga kurang berani melakukan terobosan (Susilowati, 2009:35). Legalitas hasil produksi diurus oleh pengurus melalui instansi terkait karena tanpa legalitas hasil produksi tidak bisa menaikkan harga, perlu diketahui bersama produk apapun yang mampu merambah pasar dan mall harus mempunyai ijin legalitas apalagi jenis makanan.

\section{Meningkatkan Komoditas Tanaman Padi Organik}

Ketika organisasi kelompok tani Qoryah Tayyibah dibangun atas dasar nilai-nilai agama, maka setiap aktifitasnya selalu mengedepankan nilai-nilai agama, dapat dilihat dari kegiatan rutinitasnya di lapangan. Pada proses sebelum dan dimulainya penanaman oleh pengurus sangat disarankan perilaku serah diri kepada Allah dengan membaca shalawat. Hal ini dilakukan sebagai bukti pada dasarnya manusia itu tidak punya kekuatan apa-apa, posisinya lemah, dan berserah. Agar manusia disayang oleh Allah sebagai umat Islam harus memuji-muji melalui shalawat kepada kekasih Allah, Muhammad SAW, karena dengan cara bershalawat, mereka memiliki keyakinan yang kuat akan pertolongan Allah akan hambanya.

Pada saat penanaman padi dibutuhkan biaya yang tidak sedikit, apabila salah satu anggota tidak mampu mencukupi biaya yang akan digunakan proses menanam padi, maka jalan keluarnya adalah anggota tersebut akan dipinjami oleh organisasi yang menaunginya, dan pengembaliannya dilakukan saat panen. Setelah terjadi panen raya, pada umumnya hasil produksi padi organik akan dijual melalui pengurus dan tidak boleh menjualnya secara bebas ke pasar-pasar, hal itu dilakukan bukan untuk membatasi kebebasan petani akan tetapi justru melindungi harga padi organik agar tidak terpuruk di pasaran. Sangat berbeda jauh dengan petani pestisida yang tidak ada seorangpun melindungi petani, mulai dari persiapan menanam, proses perawatan, dan panen raya. Pada umumnya petani pestisida ketika terjadi panen raya harga jatuh tidak terkendali dan pemerintahpun tidak berdaya dalam menghadapi persoalan tersebut. Hal ini sesuai 
dengan pendapat Syahyuti (2003:34) mengatakan, bahwa petani pestisida sangat bergantung dengan kebijakan pemerintah, padahal selama ini pemerintah belum bisa mandiri termasuk dalam bidang pertanian masih menjadi agen dari kapitalis dunia.

Selain hal tersebut di atas mereka memiliki hubungan yang sangat erat di antara anggotanya, terlihat pada satu kegiatan, misalnya ketika salah satu anggota mengalami musibah dengan sendirinya mereka akan membantu tanpa harus disuruh oleh organisasinya, selain dalam bentuk bantuan berupa tenaga ataupun materi. Fakta lainnya bentuk kekeluargaan mereka di saat anggota tersebut punya hajat mereka diundang dan datang, padahal kalau dilihat secara geografis tempat tinggal mereka sangat berjauhan karena sebagaimana fakta tersebut di atas anggota kelompok tani Qoryah Tayyibah terdiri dari petani Salatiga, Kabupaten Semarang, dan Boyolali.

Pada tahun 2008, kelompok tani Qoryah Toyyibah menidirikan koperasi untuk mencukupi kebutuhannya sendiri, hal itu muncul karena pengalaman di lapangan yang selama ini terjadi, misalnya pada saat jatuh musim tanam kebiasaan petani masih sangat lemah dalam manajemen yaitu persoalan keuangann untuk membiayai kebutuan penanaman, fungsi koperasi tidak hanya berhenti pada hal tersebut, tetapi dalam perjalanan lebih luas dari itu. Sampai saat ini, perkembangan koperasi mampu menyediakan dana untuk pembelian beras atau padi dari anggotanya, sehingga harga padi tetap stabil. Selain hal tersebut koperasi juga menyediakan dana untuk anggotanya, namun masih sebatas pada kebutuhan-kebutuhan mendadak dan jumlahnya tidak begitu besar, akan tetapi keberadaannya sangat membantu anggotanya. Sebagaimana yang disampaikan oleh Agim, bahwa ia sangat merasakan keberadaan koperasi, yang mampu menyediakan dana untuk kebutuhan tanam padi, terutama pada saat musim tanam padi dating.

\section{Simpulan}

Dari penelitian ini diperoleh beberapa kesimpulan, bahwa pemberdayaan masyarakat kelompok tani Qoryah Toyyibah pada perjalannanya menunjukkan kemajuan yang signifikan baik dari jumlah anggota dan kualitas produksinya, terutama bagaimana dalam melindungi kelompoknya. Dalam mengembangkan usaha untuk peningkatkan komoditas padi organik untuk kesejahteraan anggotanya mereka melalui beberapa langkah diantaranya, dengan melakukan pertemuan-pertemuan rutin yang membahas kekurangan dan kelebihan anggotanya agar tetap bisa bertahan dalam 
menghadapi kopetisi yang semakin berat, selain hal tersebut kelompok tani ini juga mendirikan koperasi guna menghadapi kesulitan keuangan dalam masa tanam, dan beberapa kebutuhan mendadak yang berhubungan dengan keuangan yang sifatnya kecil, namun keberadaan koperasi ini sangat membantu anggotanya.

Kerjasama antar kelompok perlu ditingkatkan lagi, dengan cara pertemuan yang sifatnya terjadwal dan insidental guna membahas isu-isu yang segera ditangani, tidak menunggu pertemuan tiap bulan saja, sehingga keberadaan kelompok tani bisa lebih kuat, dan pada gilirannya punya kekuatan untuk memperluas jumlah anggotanya. Para petani seharusnya memiliki kemampuan manajemen keuangan dengan baik, sehingga pada musim tanam keuangan cukup bisa disediakan sendiri tidak bergantung pada pihak lain.

\section{Daftar Pustaka}

Arikunto, Suharsimi. 2002. Prosedur Penelitian: Suatu Pendekatan Praktek. Jakarta: Rineka Cipta.

Setiawan, Avi Budi. 2008. "Analisis Efisien Penggunaan Faktor-Faktor Produksi Usaha Tani Padi di Kabupaten Grobogan tahun 2008". Skripsi. Semarang: Unnes.

Mayo, M. 1994. Community Work", dalam Hanvey and Philpot (eds), Practising Social Work. London: Routhledge..

Nasdian, Fredian Tonny. 2014. Pengembangan Masyarakat. Jakarta: Yayasan Pustaka Obor Indonesia

Payne, M. 1995. Social Work and Community Care, London: McMillan.

Sukirno, Sardono. 2005. Micro Ekonomi Teori Pengantar. Jakarta: Raja Grafindo Persada.

Sucihatiningsih. 2010. "Model Penguatan Kapasitas Kelembagaan Penyuluh Pertanian dalam Meningkatkan Kinerja Usaha Tani: Studi Empiris di Provinsi Jawa Tengah”. Disertasi. Semarang: Universitas Diponegoro.

Susilowati, Indah. 2009. "Penguatan Kinerja Agribisnis Tanaman Pangan Unggulan Provinsi Jawa Tengah dalam Mendukung Ketahanan Pangan”. Penelitian Sosial Ekonomi Pertanian. Kerjasama Undip dan badan Litbang. Deptan.

Suryana, Sawa. 2007. "Analisis faktor-faktor yang mempengaruhi produksi Jagung di kabupaten Blora (Studi Kasus Produksi Jagung Hibrida di Kecamatan Banjarejo Kabupaten Blora)". Tesis. Semarang: Universitas Diponegoro.

Suryana. 2009. Pendidikan Kewirausahaan. Jakarta: Salemba. 